\title{
Soft tissue tumors - Histopathological study of 93 cases
}

\author{
Bashar A. Hassawi*, Abdulkarem Y. Suliman*, Intisar S. Hasan** \\ *Department of Pathology, College of Medicine, University of Mosul; \\ **Department of Pathology, College of Medicine, University of Dohuk.
}

(Ann. Coll. Med. Mosul 2010; 36 (1 \& 2): 92-98).

Received: $22^{\text {nd }}$ Dec 2009; Accepted: $9^{\text {th }}$ Jun 2010.

\begin{abstract}
Objective: Histopathological and immunohistochemical examination of soft tissue tumors to assess the value of these techniques in verifying the primary diagnosis and their classification.

Methods: A prospective study of 93 consecutive soft tissue biopsies that reached the department of histopathology, central labs, Dohuk, and application of immunohistochemical markers on 27 biopsies.

Results: Out of 93 soft tissue tumors, $70(75.2 \%)$ were benign with mean age $27.6 \mathrm{y}$. and 23 cases $(24.8 \%)$ were malignant with mean age $39.1 \mathrm{y} .$. Immunohistochemistery was performed in 27 cases; $21(77.7 \%)$ cases of malignant tumors and $6(22.3 \%)$ benign cases. The most common benign tumors were Lipoma, Haemangioma, Neurofibroma, while malignant muscle tumors (leiomyosarcoma and Rhabdomyosarcoma) and malignant round cell tumors (Ewing's sarcoma/ PNET) were the major groups .

Conclusion: High quality $\mathrm{H}$ and $\mathrm{E}$ stained section, remain the best method for establishing the primary diagnosis of soft tissue tumors, but immunohistochemical examination proved extremely helpful in sub classifying them, where 7 out of 9 cases of gastrointestinal tumors (GISTs) showed strong immunoreactivity with ( $c-$ kit proteins) $C D_{117}, C D_{34}$, while other (non GISTs) tumors were negative.
\end{abstract}

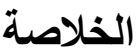

الههف: استعمال الفحوصات النسيجية والكيمياوية النسيجية المناعية للتوصل الى التشخيص النهائي وتصنيف أورام الأنسجة الرخوة. الطريقة والنموذج المستخدم: دراسة مستقبلية لـ بو خزعة نسيجية مأخوذة من أورام الأنسجة الرخوة واستعمال

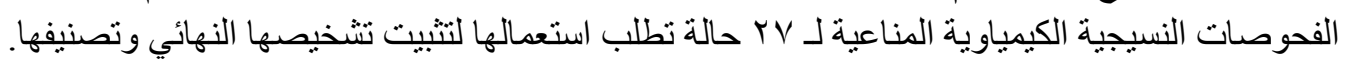

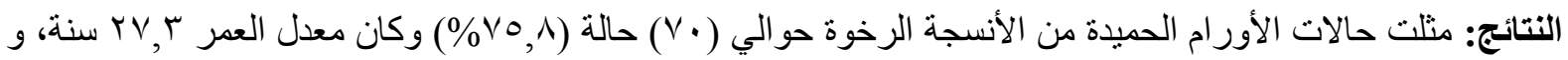

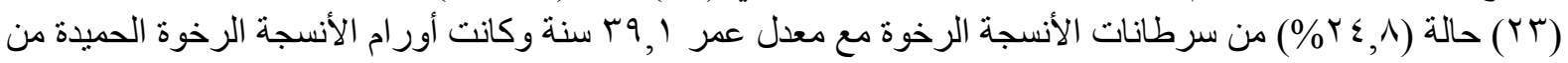

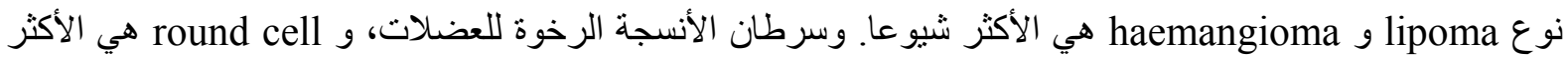

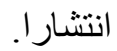
الاستنتاج: الصبخة النسيجية من نوع H and E هو أفضل طريقة وتمثل حجر الزاوية للتشخيص النهائي لأورام الأنسجة

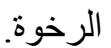

$S$ oft tissue tumors (STTs) are defined as mesenchymal proliferations that arise in the extra skeletal nonepithelial tissue of the body exclusive of the viscera, coverings of the brain and lymphoreticular system ${ }^{(1)}$. STTs are classified according to the tissue that they recapitulate or principally based on line of differentiation of tumors, rather than the type of tissue from which they developed. They include tumors of voluntary muscle, fat, fibrous 
tissues, tumors of vessels serving them and peripheral nervous tissues. However, in some STTs, no corresponding normal counterpart is known ${ }^{(2)}$.

Soft tissue tumors (STTs) are infrequent neoplasms with the exception of skeletal neoplasms, However, benign tumors outnumber their malignant counterpart at least 100:1 due to their rarity as well as the variation and frequent overlap in their histopathological features, accurate diagnosis of STTs is a constant challenge to pathologists ${ }^{(2,3)}$.

Over the years, the role of one of these ancillary diagnostic procedures (Immunohistochemistery $\mathrm{IHC}$ ) has greatly enhanced our capability to properly diagnose these tumors, from these markers (actin, desmin, vimentin, $S$ - 100 protein, neuron specific enolase (NSE), cytokeratin, $\mathrm{CD}_{99}$, $\mathrm{CD}_{117}$, EMA, myoglobulin, AFP) (table 1).

Soft tissue tumors (STTs) arise anywhere in the body, about $(50 \%)$ occur in the extremities (arm, legs, hands or feet), (40\%) occur in the trunk (chest, hips, back, shoulders and abdomen) and (10\%) occur in the head and neck ${ }^{(4)}$.

Soft tissue tumors (STTs) usually affects old persons as about $40 \%$ of the affected are 55 years old or older and only $15 \%$ are younger than 15 years ${ }^{(2)}$. Certain prognostic factors for (STTs) should be taken in consideration in order to predict the outcome of tumor which include the age at presentation, size and site of the tumors, tumors' grade and histological subtype ${ }^{(5,6)}$, and factors associated with poor prognosis including old patient ( $>60$ years) tumor size $(>5 \mathrm{~cm})$ and high grade histology with deep seated tumors ${ }^{(7)}$.

\section{Aims of the study}

1. To assess the relative frequency of soft tissue tumors.

2. To assess the role of immunohistochemical markers in the primary diagnosis and subclassification of soft tissue tumors.

\section{Materials and methods}

During a period of one year (from 2007 2008) a 93 cases of soft tissue tumor were collected from Azadi Teaching Hospital. Data collected from each patient includes age, sex, cheif complaint, site of lesion and history of trauma.

The following histopathological and immunohistochemical techniques were used:

1. Routine $\mathrm{H}$ and $\mathrm{E}$ staining method was applied for primary diagnosis and subtyping of soft tissue tumors were performed on each case.

2. Standard Avidin - biotin peroxidase complex $(A B C)$ and the following immunohistochemical markers (actin (smooth muscle actin), desmin, vimentin, $S$ - 100 protein, neuron specific enolase (NSE), cytokeratin, $\mathrm{CD}_{99}, \mathrm{CD}_{117}, \mathrm{EMA}$, myoglobulin, AFP). (table 1) were applied on 27 cases as needed.

\section{Result}

During a period of one year, 93 cases of soft tissue tumors were collected. There were (70) cases $75.2 \%$ of benign soft tissue tumors with mean age of $27.6 \mathrm{y}$. and (23) cases (24.8\%) malignant one with mean age of $39.1 \mathrm{y}$. (table 2).

The most frequent benign tumors were: lipoma, hemangioma and neurofibroma, while the malignant muscle tumors (Leiomyosarcoma and Rhabdomyosarcoma) and malignant round cell tumor (Ewing's sarcoma / PNET) were the major group of sarcomas (table 3 ).

Table (1): Markers most commonly used to correlate with histogenesis.

\begin{tabular}{|c|c|}
\hline Histogenesis & Markers \\
\hline $\begin{array}{l}\text { 1- Mesenchymal } \\
\text { (general) }\end{array}$ & Vimentin \\
\hline 2- Epithelial & $\begin{array}{l}\text { Cytokeratin, Epithelial } \\
\text { Membrane Antigen (EMA) }\end{array}$ \\
\hline 3- Smooth muscle & $\begin{array}{l}\text { Desmin, actin (smooth } \\
\text { muscle actin) }\end{array}$ \\
\hline 4- Skeletal muscle & Myoglobin \\
\hline 5- Fibrohistiocytic & Vimentin, CD68, factor XIIIa \\
\hline 6- Melanocytes & HMB45. S - 100 protein \\
\hline 7- Neuronal & $\begin{array}{l}S-100 \text { protein, glial fibrillary } \\
\text { acidic protein }\end{array}$ \\
\hline 8- Endothelial & Factor VIII, $\mathrm{CD}_{34}$, factor XIIIa \\
\hline 9- Neuroendocrine & Neuron-specific enolase \\
\hline $\begin{array}{l}\text { Ewing's } \\
\text { sarcoma / PNET }\end{array}$ & $\begin{array}{l}\text { (NSE), chromogranin, } \\
\text { synaptophysin } \mathrm{CD}_{99}\end{array}$ \\
\hline
\end{tabular}


The immunostaining was used in 27 cases depending on the differential diagnosis which was highlighted by $\mathrm{H}$ \& $\mathrm{E}$ staining where 7 cases of gastrointestinal stromal tumors out of 9 cases show positive immunoreactivity for $\mathrm{CD}_{117}, \mathrm{CD}_{34}((\mathrm{c}-$ kit proteins $))$ (table 4$)$.

Table (3): Histological types of soft tissue tumors.

\begin{tabular}{|c|c|c|c|c|c|}
\hline Histological types & Benign tumors & $\begin{array}{c}\text { Total } \\
\text { number }\end{array}$ & Malignant tumors & $\begin{array}{c}\text { Total } \\
\text { number }\end{array}$ & Total \\
\hline Tumor like lesions & & 16 & & & 16 \\
\hline Adipose tumors & lipoma & 20 & Liposarcoma & 3 & 23 \\
\hline Vascular tumors & $\begin{array}{l}\text { Hemangioma \& } \\
\text { glomus tumor }\end{array}$ & 22 & Kaposi sarcoma & 1 & 23 \\
\hline Fibrohistiocytic tumors & $\begin{array}{l}\text { Giant cell tumor of } \\
\text { tendon sheath }\end{array}$ & 2 & $\begin{array}{l}\text { Malignant fibrous } \\
\text { histiocytoma }\end{array}$ & 2 & 4 \\
\hline Neuronal tumors & $\begin{array}{l}\text { Neurofibroma } \\
\& \text { schwannoma }\end{array}$ & 8 & Malignant schwannoma & ---- & 8 \\
\hline $\begin{array}{l}\text { Smooth and skeletal } \\
\text { muscle tumors }\end{array}$ & $\begin{array}{l}\text { Rhabdomyoma } \\
\text { \& leiomyomas }\end{array}$ & 2 & $\begin{array}{l}\text { Rhabdomyosarcoma } \\
\text { \& leiomyosarcomas }\end{array}$ & 11 & 13 \\
\hline others & & & $\begin{array}{l}\text { Synovial sarcoma } \\
\text { PENT / Ewing's tumor }\end{array}$ & $\begin{array}{l}1 \\
5\end{array}$ & $\begin{array}{l}1 \\
5\end{array}$ \\
\hline total & & 70 & & 23 & 93 \\
\hline
\end{tabular}

Table (4): Histological types and its immnuoreactivity.

\begin{tabular}{|c|c|c|c|c|c|c|c|c|c|c|c|c|}
\hline Type of tumour & $\begin{array}{l}z \\
0 \\
0 \\
0 \\
\mathbb{8} \\
\mathbb{8} \\
\mathbb{\infty} \\
\infty\end{array}$ & 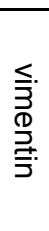 & 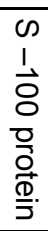 & 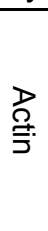 & 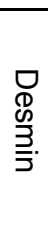 & 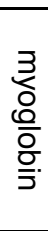 & 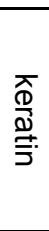 & $\begin{array}{l}0 \\
0 \\
6\end{array}$ & z & 片 & 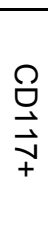 & $\underset{⿱ 亠 乂}{\mathrm{~m}}$ \\
\hline Ewing's sacrcoma / PNET & 5 & + & + & & & & & + & + & & & \\
\hline Rhabdomyo sarcoma & 3 & & + & & + & + & & & & & & \\
\hline Synovial sarcoma & 1 & & & & & & + & & & & & \\
\hline Schwannoma & 2 & & + & & & & & & & & & \\
\hline Neurofibroma & 1 & & + & & & & & & & & & \\
\hline Leiomyosarcoma & 1 & + & & + & + & & & & & & & \\
\hline $\begin{array}{l}\text { Gastrointestinal stromal tumor } \\
\text { (GIST) }\end{array}$ & 9 & & & + & & & & & & & + & \\
\hline MFH & 2 & + & & & & & & & & & & \\
\hline Liposarcoma & 1 & + & & & & & & & & & & \\
\hline Spindle cell lipoma & 1 & & & & & & & & & & & \\
\hline Glomus tumor & 1 & + & + & + & & & & & & & & \\
\hline Total & 27 & & & & & & & & & & & \\
\hline
\end{tabular}




\section{Discussion}

Soft tissue tumors (STTs) constitute a large and heterogeneous group of neoplasm that involves muscles, fat, fibrous tissue with their supplying vessels and peripheral nerves.

Soft tissue sarcoma is a disease of the adult, occurring most commonly in persons between 30 and 60 years of age, except few types like embryonal, and botryoid rhabdomyosarcoma occur in young children. The mean age was $39.1 \mathrm{yr}$; a finding compatible with others (table 2) ${ }^{(8)}$.

Although clinical information regarding age, site, size of the lesions are critical for the diagnosis of STTs, but histological examination remains the cornerstone for their diagnosis. However, certain complementary methods like EM and immnunohistochemical examination (IHC) may be needed to confirm the diagnosis and to establish their classification ${ }^{(9)}$.

The IHC should be applied after careful $\mathrm{H}$ \& $E$ examination in order to limits the number of markers selected in every specific case. In this study many markers were applied for confirmation of diagnosis.

Vimentin is the most known broad spectrum marker for detection of mesenchymal tumors. It is an intermediate filament protein where the desmin and cytokeratin belong to this group of cytoskeleton. In general vimentin reacts with fibroblasts, Endothelial cells and smooth muscle of leiomyoma of the uterus (but not with that arising in the gastrointestinal tract) $(10,11)$

This wide variation in immunoreactivity of vimentin makes it of limited diagnostic value. In this study many benign and malignant tumors were positive for vimentin (table 4). Due to the lack of specific markers for fibrohistiocytic tumors, Vimentin is known as the only marker positive in fibrohistiocytic tumors, that is why the diagnosis of these tumors is based on the absence of markers of other lineages ${ }^{(12)}$. In this study there were two cases of MFH showing strong immunoreactivity for vimentin.

S-100 protein is widely distributed in peripheral (Schwann cells) and central nervous system (Astrocytes and oligodendrocytes) as well as melanocytes indicates that these cells are both considered to arise from neural crest, the result of this study confirms this correlation ${ }^{(13)}$, but it is also appeared in other tumor that does not show neuronal differentiation like glomus tumor (table 4) .

Actin is a marker which is expressed in tumors that arise from striated and smooth muscle fibers like leiomyoma, rhabdomyoma, rhabdomyosarcoma and leiomyosarcoma as well as few types of vascular tumors like glomus tumor and hemangiopericytoma; these contractile proteins are classified as alpha (skeletal, cardiac and smooth muscle) and beta (cytoplasmic) and gamma (smooth muscle and cytoplasmic) ${ }^{(14)}$. In this study actin was positive with the above mentioned tumors except for rhabdomyosarcoma because we use smooth muscle actin where the specificity of smooth muscle actin is more restricted (it doesn't detect skeletal and cardiac muscle actin). These results were compatible with others ${ }^{(15-16)}$.

Desmin is intermediate filament markers for skeletal, cardiac and smooth muscle; it is expressed in $95 \%$ of Rhabdomyosarcoma and variable smooth muscle tumor Fig. $\left(1_{\mathrm{A}}, \mathrm{B}\right)$. Other tumors may share this reactivity like $\mathrm{MFH}^{(17)}$, this expression of conventional markers of muscle fiber tumors in some cases of MFH may raise the questions about the nature of this tumor and its histogenesis.

Myoglobin represents a specific marker for neoplastic striated muscle cells, i.e. "Rhabdomyosarcoma" which includes different histological subtypes (i.e., embryonal, botryoid, alveolar, pleomorphic) ${ }^{(18,19)}$. In the current study 3 cases of rhabdomyosarcoma were positive for Myoglobin.

Myxoid liposarcoma in this study was negative for all markers, although few cases of liposarcomas express focal reactivity for S-100 protein ${ }^{(20)}$; a finding compatible with others Fig $\left(2_{\mathrm{A}, \mathrm{B}}\right)$.

Gastrointestinal stromal tumors (GISTs) comprise the largest subset of mesenchymal tumors of the gastrointestinal tract, they are characterized by expression of tyrosine kinase growth factor receptors (c-Kit antigen). These 
neoplasms differ immunohistologically and behaviorally from other mesenchymal tumors such as leiomyosarcoma which does not express Kit antigen. Most GISTs express $C_{34}$ and $\mathrm{CD}_{117}$ (c-kit protein) but not desmin ${ }^{(21)}$. In the current study there were 9 cases of GISTs (8 malignant and one benign), 7 cases were positive for $C_{117}$ and $C_{34}$, which was compatible with others ${ }^{(22)}$.

Both cell surface antigen P30/ $32\left(\mathrm{CD}_{99}\right)$ and NSE are markers of tumors that express a neural differentiation ${ }^{(23)}$. These include Ewing's sarcoma of bone and soft tissue (Fig. 3) and primitive neuroectodermal tumor (PNET) where molecular studies have recently revealed that (PNET) and Ewing's sarcoma entities that once considered unrelated, are perhaps best considered as members of the same family ${ }^{(24,25)}$. In this study there were 5 cases all were positive for these markers, a result matched with other studies ${ }^{(26)}$.

In this study the malignant tumors constitute about quarter of all STTs, and this result does not reflect the accurate incidence of malignant tumors, because not all benign tumors are excised and rarely sent for histopathological examination.

Finally the IHC is a good tool in the differentiation between large numbers of soft tissue tumors and it is an indispensable procedure for the solution of the diagnostic challenges facing the pathologist.

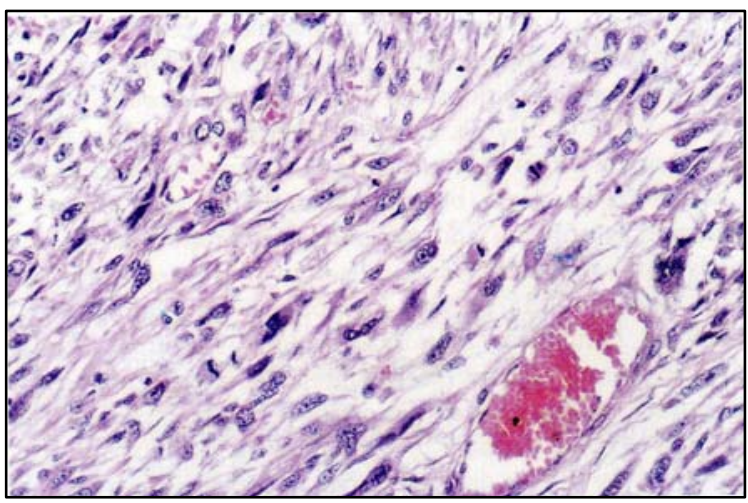

Figure (1-A): Leiomyosarcoma. This tumor consists of elongated cells with a cigar shaped nucleus and eosinophilic cytoplasm, with several mitosis.

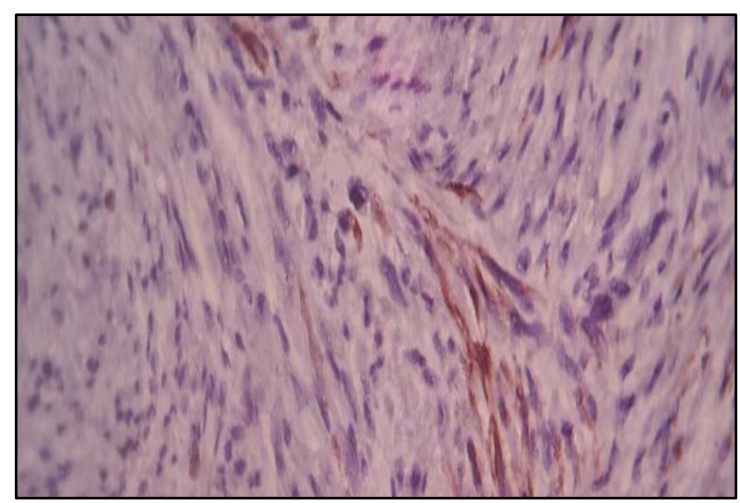

Figure (1-B): Desmin in leiomyosarcoma.

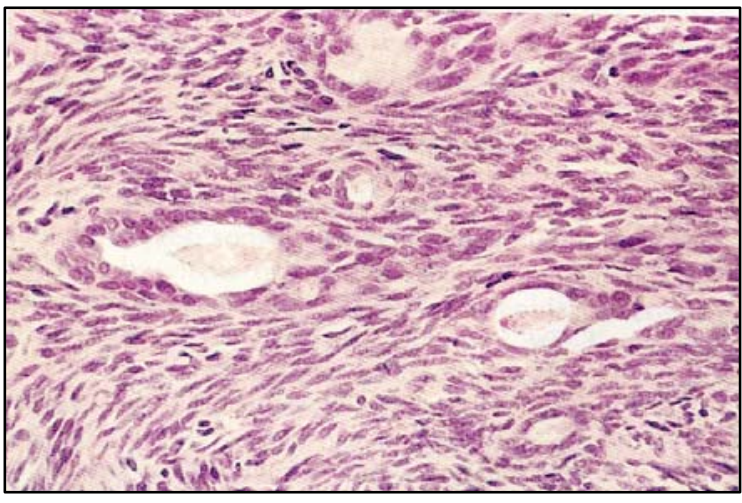

Figure (2-A): Synovial sarcoma exhibiting a classic biphasic spindle cell and gland - like histologic appearance.

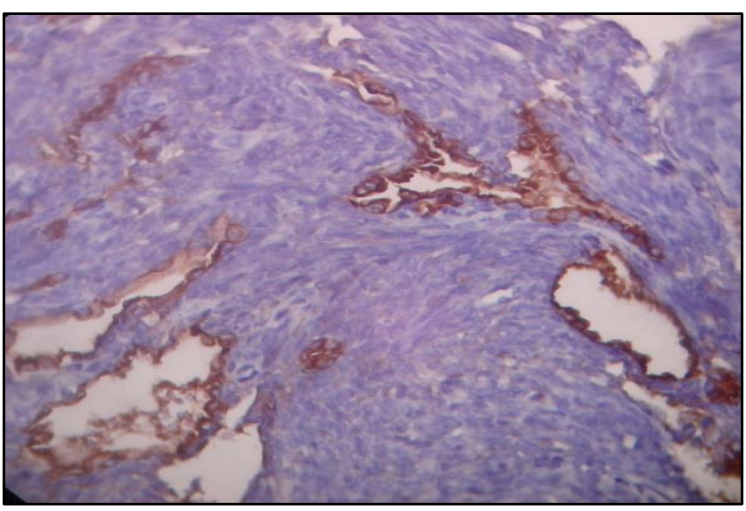

Figure (2-B): "Epithelial Membrane Antigen" (EMA) In Synovial sarcoma. 


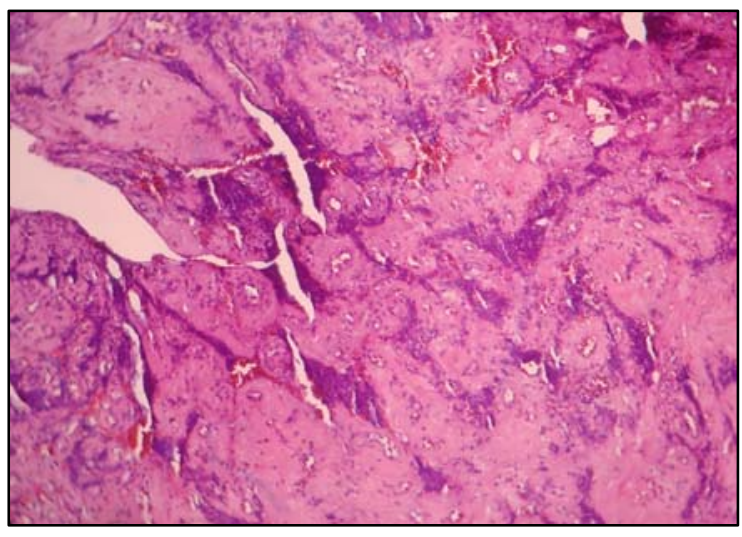

Figure (3): Ewing's sarcoma ( $\mathrm{H}$ and $\mathrm{E}$ stain) sheets of small round cells slightly larger than lymphocytes.

\section{Conclusion}

1. $H$ and $E$ stained sections remain the best method for establishing the primary diagnosis of soft tissue tumors.

2. Immunohistochemistry is of great help in accurate categorization of both benign and malignant tumors particularly (c-kit protein) $\mathrm{CD}_{117}, \mathrm{CD}_{34}$ in GISTs .

\section{References}

1. Kumar. V, Abbass. Abul k, Fausto. N, Mitchell. R. Robbins Basic pathology $8^{\text {th }}$ edition SAUNDERS ELSEVIER, the muscloskeletal system. 2007; 801-836.

2. Enzinger F.M. Weisss S.W: soft tissue tumors $2^{\text {nd }}$ edition. Mosby st. Louis. USA 1988. p 2.

3. Rydholm A. Berg No, Gullberg B. et al. Epidemiology of soft tissue sarcoma in the locomotor system. A retrospective population - based study of the inter relationships between clinical and morphologic variables. Acta Pathol Microbiol Immunol Scand 1984; 92:363374.

4. Jauice N Cormier and Raphael E Pollock. Soft Tissue Sarcomas. CA Cancer J Clin 2004; 54:94-109.

5. Le Doussal V, Coindre JM, and Leroux A, et al.: Prognostic factors for patients with localized primary malignant fibrous histiocytoma: a multicenter study of 216 patients with multivariate analysis. Cancer 1996; 77 (9): 1823-30.
6. Coindre JM, Terrier $P$, and Guillou $L$, et al.: Predictive value of grade for metastasis development in the main histologic types of adult soft tissue sarcomas: a study of 1240 patients from the French Federation of Cancer Centers Sarcoma Group. Cancer 2001; 91 (10): 1914-1926.

7. Mondard A.M., Petiot J.F Marnay., et al. Prognostic factor in soft tissue sarcoma. A multivariate analysis of 109 cases. Cancer 1989; 63: 1437-1451.

8. Dcnk. H, Krepler R, Artlieb, et al. Protein of intermediate filaments. An immunohistochemical and biochemical approach to the classification of soft tissue tumors. American journal of pathology. 1983; 10: 193-208.

9. Brooke JS. Immunohistochemistry in the differential diagnosis of soft tissue tumors Monogr Pathol. 1996 ; 38: 65-128.

10. Gabbiani G, Schmid E, Winter S, et al.: Vascular smooth muscle cells; Predominance of vimentin and a specific a-type actin. Proc Natl Acad Scince USA 1981; 78: 298-302.

11. Cohn PR, Rapin RP, Farhood Al. Dermatofibroma and dermatofibrosarcoma protuberans: differential expression of CD34 and factor XIlla. Am J Dermatopathol. 1994; 16:573-574.

12. Carlos A. Muro Caco. The role of immunohistochemistry in the differential diagnosis of soft tissue tumor. Cancer control Journal1998; 5:53-63.

13. Stefansson K ., Wollmann R ., Jerkovic M. S-100 protein in soft tissue tumors derivedlrom Schwanffcells and melanocytes. Am J Pathol. 1982; 106:261268.

14. Franquemont. DW. Muscle actin antibodies. Am J. Clin Pathol. 1993; 99: 353.

15. Schurch. W, Skalli. O, Lagacel. R, et al. Intermediate filament proteins and actin isoforms as markers for soft tissue tumor differentiation and origin. Am $\mathrm{J}$ Pathol. 1990; 136:771-786.

16. Miettinin. M, Antibody specific to muscle actins in the diagnosis and classification of 
soft tissue tumors. Am J Pathol. 1988; 130:205-215.

17. Truong LD, Rangdaeng S, Cagle $P$, et al. The diagnostic utility of desmin. A study of 584 cases and review of literature. Am J. Clin Pathol. 1990; 93:305-314.

18. Corson. M. J, Pinkus. G. S, Intracellular Myoglobin -a specific marker for skeletal muscle differentiation in soft tissue sarcoma, an immune peroxidase study. Am J patholo. 1988; 103: 384- 389.

19. Tallin. G, Parham. M.D, et al. Myogenic regulatory protein expression in adult soft tissue sarcomas. A sensitive and specific marker of skeletal muscle differentiation. Am J Pathol. 1994; 144:693-701.

20. Coccchia D, Lauriola L, Stolfi VM, et al. S100 antigen labels neoplastic cell in liposaarcoma and cartilaginous tumors. Virchows Arch (A) 1983; 402:139-145.

21. Lasota. J, Jasinski, M, et al. Mutations in Exon 11 of c-Kit Occur Preferentially in Malignant versus Benign Gastrointestinal Stromal Tumors and Do Not Occur in Leiomyomas or Leiomyosarcomas. Am J Pathol. 1999; 154:53-60.
22. Mieltinen M, Lasota J. Gastro intestinal stromal tumor "definition, clinical, histological, immunohistochemical and molecular genetic features and differential diagnosis. Virchows Arch 2001; 438: 1 -12 " midline ".

23. Sohn. W.H, Choi. Y. J, et al. Engagement of CD99 Induces Apoptosis Through a Calcineurin-Independent Pathway in Ewing's Sarcoma Cells. Am J Pathol 1998;153:1937-1945.

24. Seshi. B, True. L, et al. Immunohistochemical characterization of a set of monoclonal antibodies to human neuron-specific enolase.. Am J. Pathol 1988;131: 258-269.

25. Cavazzana AO, Miser. J. S, et al. Experimental evidence for a neural origin of Ewing's sarcoma of bone. Am J Pathol. 1987; 127:507-518.

26. Stevenson AJ, Chatten J, Bertoni F. et al (CD $\left.{ }_{99}\right)$ P30/ 32 MIC 2 Ewing's sarcoma / PNET antigen as an immunohistochemical marker: review of more than 600 tumors and literature experience Appl immunohistocheme. 1994; 2: 231- 240. 